DOI: $\underline{10.20472 / B M .2016 .4 .4 .003 ~}$

\title{
SUBSTANTIVE INCUBATION FOR GROWTH AND ITS ICT IMPACT ON MSME'S
}

\author{
SUFIA KAMAL LASKAR, KHALID WAHEED
}

\begin{abstract}
:
A business incubator gives assistance to the startups for decreasing the high failure rate. It provides clustering opportunities, business support services, networking opportunities and incubator space to accelerate and systemize the creation process of successful enterprises. It generates new business steady flow with above wealth creation potential and average job. The main objective of this paper is to permit substantive incubation for the development and its impingements on Micro Small and Medium Enterprises (MSME). An ICT incubator provides training to 100 MSME. It gives technical help, consultation and guidance to entrepreneurs. Training is carried out in two stages for MSME; Pre-Incubation and Post Incubation. The functioning of 100MSME in pre- incubation stage is compared with the post-incubation stage. The comparison shows that training, connectivity, finance, infrastructure and business service in post-incubation stage is efficient than pre-incubation stage.
\end{abstract}

\section{Keywords:}

- Business Incubator, Business Service, Connectivity, Finance, ICT incubator, Infrastructure, MSME and Training.

JEL Classification: L26

\section{Authors:}

SUFIA KAMAL LASKAR, B.S.Abdur Rahman University,Chennai, India, Email:

sufiakamallaskar@gmail.com

KHALID WAHEED, Dept.of Mgt.Studies, BSA Uinversity, Channai, India, Email: kwfalahi@bsauniv.ac.in

\section{Citation:}

SUFIA KAMAL LASKAR, KHALID WAHEED (2016). Substantive Incubation for growth and its ICT impact on MSME's. International Journal of Business and Management, Vol. IV(4), pp. 53-77.,

10.20472/BM.2016.4.4.003 


\section{INTRODUCTION}

A business incubator is a famous tool that accelerates to create successful entrepreneurial companies. In the European Union and US, there are about 900 and 1400 business incubators. It supports the new venture because it is in hope that it will develop into thriving and self- sustaining company. It provides business report, shared resources, access to networks and office spaces (e.g. Barrow, 2001) [1]. While serving the clients, a good incubator recognizes belonging and a sense of community along with the best business practices instruction, supplies and facilities they offer. For an effective incubation program, developers should invest money and time to lay the foundation. In the success of an incubator, an effective study will be useful in determining whether the proposed project has strong community support and a sound financial base. In local and regional economies, government subsidies for an incubation program of well managed business incubation characterize a strong investment. In 2010, a set of industry guidelines for helping an incubator manager to serve their clients better is developed by NBIA's. Substantial employment is provided by the Micro Small and Medium Enterprises and across the society, it distributes the economic wealth uniformly.

The MSME constitutes over $90 \%$ of total enterprises in many developing countries like India, Sri Lanka, Brazil and Pakistan. It accounts for a major share in industrial exports and products and credited with the highest rate of employment rate generation. The strength of 26 million MSMEs plays an important role in India in the countries overall industrial economy. The SME sector is calculated to contribute over 70 percent in employment and 30 to 40 percent of GDP in Egypt, Kenya, Africa and South Africa. In India, MSME calculates for about $45 \%$ of the manufacturing yield and over $40 \%$ of the country's total expert. The sector has shown important adaptability and innovativeness for surviving the recent recession and economic downturn with its potential and great flexibility all over the world. Constituting a micro or small enterprise acquires various months to years for gathering information, resources and skills and gain knowledge. A peer survey is applied to achieve this within the same industry to acquire practical advice by talking to other business men. In decision making, taking the independent research is applied to find out demand assessment, availability of raw material, marketing intelligence, identification of supply chain, appropriate technology, demand assessment and forecasting. Comprehensive and the integrated range of support is necessary for a starting entrepreneur through which they acquire finance, technology and marketing assistance, clustering and networking opportunities, spaces and business support. Business incubators provide incubates the required hand holding services and resources such as mentoring, networking with angel investors, assistance in business plan training. It assists in receiving finance. Incubators also offer shared basic office services, access to equipment and common facilities and company's rental space with flexible leases. 
Understanding the entrepreneurship challenges, Research Institutions have accomplished many Business/ Technology Incubators with the purpose to foster the start-up small enterprises. Several Governments have also started various schemes and organized incentives to help the entrepreneurs. In any country, enterprise growth leads to local economic growth. Entrepreneurs aim to initiate their business with minimum investment and risks. An incubator renders short and long-term assistances and helps to establish new enterprises. It offers business development services and provides technical assistance, guidance and consultation to entrepreneurs. In ICT incubator, clients access to shared basic services, equipment and appropriate rental space. Some incubators assist only in arranging venture capital funding and developing new ideas.

As incubators accelerate start-ups by providing support, resources and quick knowledge it is sometimes called as Business Accelerator. In developing their business, incubators helps in rising ventures by giving assistance and services. Business incubators are mapped into Corporate Private Incubators (CPIs), Business Innovation Centres (BICs), Independent Private Incubators (IPIs) and University Business Incubators (UBIs) (Rosa Grimald, 2005) [2]. Depending up on common facility equipment and leasing out infrastructure to entrepreneurs, incubation program was modeled before some years. New incubators have been set up in the food processing, ICT, Health care technologies, product design, knowledge management, arts and crafts, ceramics technologies and light engineering areas. It provides a chance to first generation entrepreneurs for acquiring skills to build enterprise and incubates them to become a successful small business owner. It gives exposure in all business operation areas like identification of appropriate technology, project / product selection, opportunity guidance including commercial aspects of business, hands on experience on working projects and business skills development.

In this paper, the Substantive Incubation for the development of MSME by the training of ICT incubators is proposed. ICT incubator training includes.

1. Finance, Connectivity, Infrastructure, Training and Business services are provided by ICT incubators to 100 MSME in pre and post incubation stages.

2. The comparison of the above factors shows that Post-incubation stage of MSME is efficient than Pre-Incubation stage.

The chapters are organized as follows. Chapter II gives the overview of review of literature on Business Incubators, ICT Incubators and MSME. Chapter III deals brief description about the ICT incubator stages that provides training to the MSME. In Chapter IV, the monitoring and the evaluation of the trained MSME are presented. In Chapter V, paired sample test is described. Chapter VI presents the analysis of the performance of the MSME in pre and post- incubation stages. 


\section{RELATED WORKS}

Nicola Dee et.al, (2011) presented an overview of current knowledge on the role and effectiveness of business incubation. It supports new firms development and reviewed the quantitative and qualitative literature which was published by the practitioner and academic communities and it concludes that in relation to business incubators, there is a widespread definitional and conceptual ambiguity in the academic and the practitioner publications and gives a variety of stakeholders, business models and incubator strategies. The comparability, generalizability and the validity of published findings of the performance of the incubator should be considered carefully [3]. Rwanda et.al, (2011) analyzed that in Rwanda, Technology and Business Incubation considered as a potential to promote technology innovation and entrepreneurship. In this paper, the empirical analysis of technology business incubation is advanced to create sustainable business in Rwanda and concluded that the whole community business incubation gives more benefits and helps in reducing poverty [4].

Kinoti Meru et.al, (2011) reviewed that for a new and the entrant Small and Medium Enterprises, the essential service network was provided by the business incubators in Kenya. They took 124 entrepreneurs to get the comparison to confirm the process of the business incubation and the ways the receiver comprehend the services [5]. Lubica Lesakova et.al, (2012) described that local phenomenon affects entrepreneurs and gets best support by the initiatives and implemented locally. Business incubators foster entrepreneurship. It speeds up the entrepreneurial company's development. In this paper, the role of the incubators to support the small and the medium entrepreneurs was described. It has three parts, the first part represents the incubator types, core of the incubators and goals, the second part represents the business incubator role in fostering entrepreneurship local dimensions and the third part describes the business incubator building in Slovakia and helps them to start entrepreneurship [6].

Pralay Dey et.al, (2012) presented that Micro and Small Enterprises (MSEs) are essential to all developing economies in the world. It have challenges, major employment and import dependency. In the first year of inception, majority of start-up fails. An institution with special incubation programmes that gives a handholding support can decrease these failures. Incubators have the potential to strengthen local and national economies, commercialize new technologies and import substitution. The major challenges for the establishment and any enterprise survival are organization sales, distribution channels, technology, Marketplaces, infrastructure, finance and sourcing of raw material [7]. Jose L. Barbero et.al, (2012) reviewed the comparison of functioning of incubator and the non incubator firm. The individual assessment is not carried out. There are various types of incubators. The features and the execution of the incubators are compared to know the growth received by the incubators [8]. 
Nkem Okpa Obaji et.al, (2012) reviewed that implementation of the incubation model of SME has not been especially successful by the Nigerian government. The disputes in Nigeria give the ways of the models obtained from anywhere have to be adjusted to local contexts for good success opportunities [9]. Simon Stephens et.al, (2012) described the business incubation impact on incubates. The abstract outline of the evaluation calculates that the incubation of the business is increased by this research. Thus the performance of the business incubation is enhanced [10]. Hung Chia et.al, (2013) described the investigation whether the timing of the venture capital (VCs) is affected by the technological changes in the industry. The incubation period was affected by the venture capital [11]. Prof M. Chandraiah et.al, (2014) described that India's Industrial sector includes the Micro, Small and Medium Enterprises. It has the MSMEs of rural/village enterprises and khadi [12]. Wen-Hsiang reviewed that the incubators of business acquire assistance for decreasing the high negative rate. It provides the exact help for getting over the difficulties in the post-entrepreneurial stage [13].

\section{Methodology}

An ICT setup that develops current theme and organize is employed. Innovation is incubated and meted out by a method that provides resources, recommendation and support in every stage of the event of the rising business. To assure the proper growth of a revolutionary business plan, we tend to acquire our methodology in 2 completely different stages; Pre-Incubation, and post incubation. The performance of the MSME is monitored and evaluated to grasp the progress in each pre- incubation and postincubation stage.

\subsection{Pre-Incubation Stage}

At the pre-incubation stage, Associate in Nursing brooder establishes the bases for changing Associate in Nursing innovative plan into productive entrepreneurship. during this stage, the project property is analyzed and the market investigation is developed to see the thanks to follow. Then, it develops the business strategy set up and interested to take a position in original concepts. The steering and therefore the business tutor support area unit provided for Medium tiny small Enterprises within the Pre- Incubation stages, backed by special consultant's network, for the expansion of technologicallyinnovative business concepts. It provides aspiring entrepreneurs with skills and has the information on remodeling their business concepts into business plans, and next into collaborating business with high-growth potential by supporting them with coaching. within the recent situation of Medium tiny small Entrepreneurs, there area unit cluster of entrepreneurs United Nations agency aren't well provided to travel to the incubation method straightly. The performance of the incubation stages is increased by providing 
pre-incubation

services.

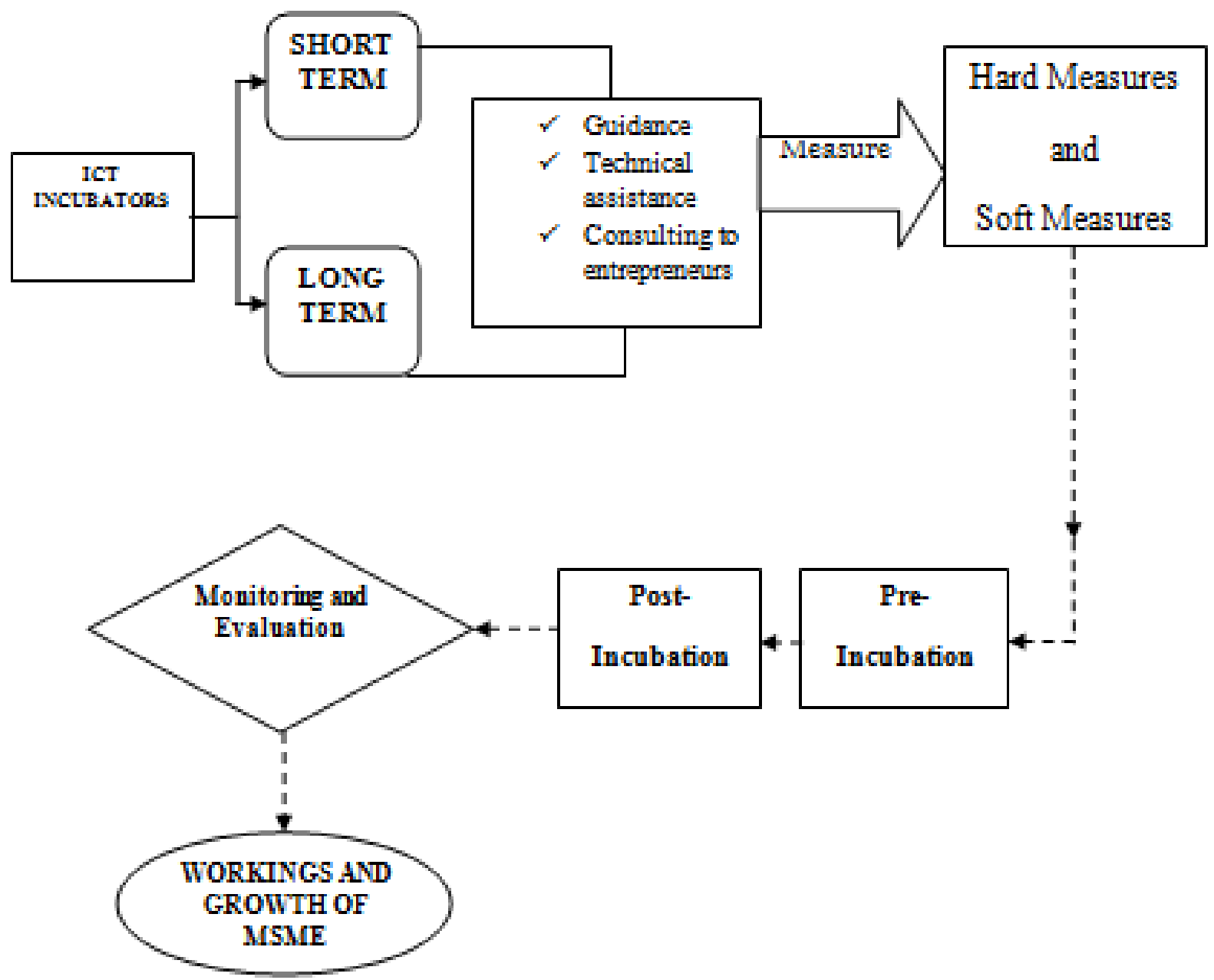

Figure 1: The framework of ICT incubator.

Figure 1 shows that ICT incubators provide short and long term assistance to provide guidance, offer business development services, consulting to entrepreneurs and technical assistance. A pre-incubation stage includes Appointment, Training, Orientation, Innovation assessments and Business plan. In appointment, the formulation of ideas, assessment of ideas and the marketing validation of ideas is done. Training is carried on the managerial skills, presentation skills and on more specialized topics (Legal and Administration). The business idea and the business model are defined in the orientation. Innovation assessment is carried out through internal and external competencies. The competition of the business plan with the financial forecasts occurs in the business model. 


\subsection{Post-Incubation Stage}

In post incubation stage, enterprises area unit allowable to use their criteria concerning the expansion of latest business objectives and methods that strengthen their opportunities areas and strengthen them within the long haul. Either as a supplier or technological partner, recommendation and support can continuously target accomplishing established objectives for every one in every of them. Coaching is enclosed on the company and debt restructuring, acquisition and managers.

It supports linkages to native and international methods partners and permits access to loans and investments. It provides the enterprises with smart infrastructure and facilities. Growth coaching is applied to deal with growth, leadership and international growth. It includes analysis and development, skilled support in feasibleness studies, preparation of business set up and preparation for acceleration and internationalization.

\section{Monitoring and Evaluation}

The Ministry of MSME monitors and guides the project. stress has to be afforded to assure the continuation of theme by documentation. AN informatory and observation committee moves within the direction by Development Commissioner (MSME) consisting of NMCC representatives and extra Secretary, Representatives of Assessment Council (TIFAC) and therefore the prediction of the technological info and banking company of the State representatives wherever the apparatus is established. It consists of Industries Association representatives below the MSMED Act, 2006. Representatives would be established to guide and review the programme implementation. The essential mid-term correction came by the Committee are going to be enforced to form AN economical program.

\section{Results and Discussions}

An analysis is carried out for Micro Small and Medium Enterprises. An ICT incubator provides guidance to $100 \mathrm{MSME}$ and it is conducted in two stages; Pre-Incubation and Post Incubation. 


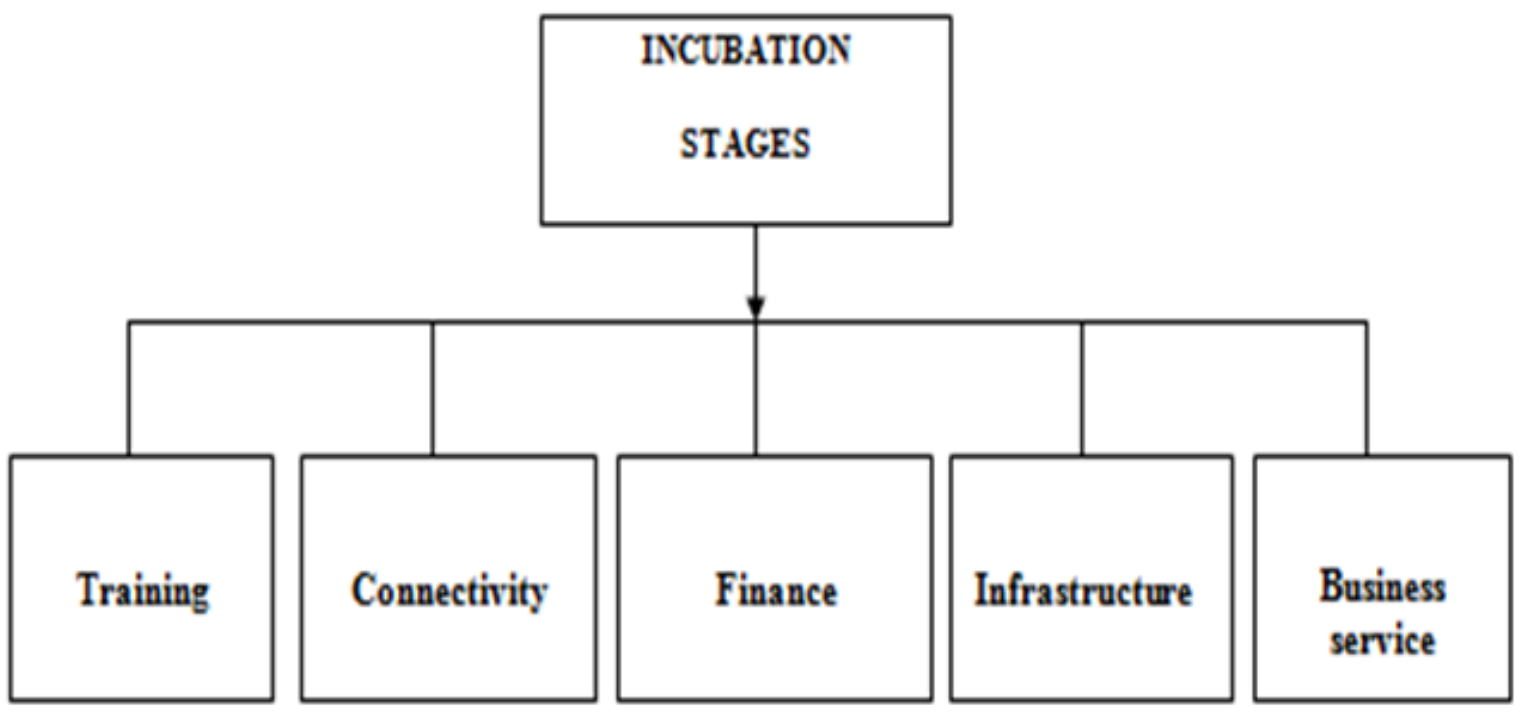

Figure 2: Incubation Stages.

Figure 2 shows that an incubation stage includes training, connectivity, finance, infrastructure and business service in pre- incubation and post-incubation stage. The functioning of $100 \mathrm{MSME}$ in pre and post-incubation stage is equated to know the progress which would assist in the growth of the enterprises.

\subsection{Paired Sample test}

The test is carried out for business management skills, linkage to local and international strategic patterns, access to finance, infrastructure and business services in both post incubation and pre incubation stages for 100 MSME. Mean value, standard deviation and standard error mean, 95\% confidence interval of the difference (lower and upper), t, $p$ and $d r$ is acquired.

\subsection{Analysis of MSME in Pre-Incubation and Post-Incubation Stage.}

\begin{tabular}{|c|c|c|}
\hline Particulars & Pre-Incubation & Post Incubation \\
\hline \multicolumn{3}{|c|}{ Business management Skills. } \\
\hline Extremely Good & 19 & 20 \\
\hline Good & 11 & 12 \\
\hline Average & 29 & 30 \\
\hline Poor & 20 & 21 \\
\hline
\end{tabular}




\begin{tabular}{|l|l|l|}
\hline Extremely poor & 21 & 17 \\
\hline Total & 100 & 100 \\
\hline
\end{tabular}

Table 1 Analysis of MSME for Business management Skills in Pre-Incubation and Post-Incubation stage.

Table 1 shows the performance of MSME in pre and post-Incubation stage. Training is very efficient in the post-incubation stage than the pre-incubation stage.

\begin{tabular}{|c|c|c|c|c|c|c|c|c|}
\hline & \multirow{2}{*}{ Mean } & \multirow{2}{*}{$\begin{array}{c}\text { Std. } \\
\text { Deviation }\end{array}$} & \multirow{2}{*}{$\begin{array}{l}\text { Std. } \\
\text { Error } \\
\text { Mean }\end{array}$} & \multicolumn{2}{|c|}{$\begin{array}{l}95 \% \text { Confidence } \\
\text { Interval of the } \\
\text { Difference }\end{array}$} & \multirow[t]{2}{*}{$\mathrm{t}$} & \multirow{2}{*}{ df } & \multirow{2}{*}{$\begin{array}{l}\text { Sig. (2- } \\
\text { tailed) }\end{array}$} \\
\hline & & & & Lower & Upper & & & \\
\hline $\begin{array}{l}\text { Business } \\
\text { management } \\
\text { skills-trained. } \\
\text { (Post and Pre } \\
\text { Incubation) }\end{array}$ & .100 & .302 & .030. & .040 & .160 & 3.317 & 99 & .001 \\
\hline
\end{tabular}

Table 2 Paired Sample Test for Business Skills

In table 2, this option shows the summary data of the sample. The statistics is given by $t$. The $t$ value is 3.317 and $p=0.004$. This means that a very few probability of this output occurring by chance, under the null hypothesis of no difference. Here $p<0.05$ $(p=0.004)$, thus the null hypothesis is neglected. There is a strong evidence $(p=0.004$ and $\mathrm{t}=3.317$ ). It shows that the post incubation increases the training; it improved training on average. If other training samples was considered, mean paired difference obtained in training differ from .100. It is important to see at the $95 \%$ confidence interval $(95 \% \mathrm{Cl})$. If the experiment is repeated 100 times, 95 times the true value for the difference would lie in the $95 \%$ confidence interval. From 0.40 to .160 the $95 \% \mathrm{Cl}$ is available. 


\begin{tabular}{|c|c|c|}
\hline Particulars & Pre-Incubation & Post Incubation \\
\hline \multicolumn{3}{|c|}{$\begin{array}{l}\text { Linkages to local and international strategic partners through maintaining events \& } \\
\text { Conferences }\end{array}$} \\
\hline Extremely Good & 21 & 22 \\
\hline Good & 13 & 14 \\
\hline Average & 31 & 32 \\
\hline Poor & 22 & 23 \\
\hline Extremely poor & 13 & 9 \\
\hline Total & 100 & 100 \\
\hline
\end{tabular}

Table 3 Analysis of MSME for Connectivity in Pre-Incubation and Post-Incubation stage

Table 3 show the performance of MSME in pre and post-Incubation stage. PostIncubation provides high connectivity compared to the Pre-Incubation stage.

\begin{tabular}{|c|c|c|c|c|c|c|c|c|c|}
\hline & \multirow[t]{2}{*}{ Observation } & \multirow[t]{2}{*}{ Mean } & \multirow{2}{*}{$\begin{array}{c}\text { Std. } \\
\text { Deviation }\end{array}$} & \multirow{2}{*}{$\begin{array}{l}\text { Std. } \\
\text { Error } \\
\text { Mean }\end{array}$} & \multicolumn{2}{|c|}{$\begin{array}{c}95 \% \text { Confidence } \\
\text { Interval of the } \\
\text { Difference }\end{array}$} & \multirow[t]{2}{*}{$\mathrm{t}$} & \multirow[t]{2}{*}{$d f$} & \multirow{2}{*}{$\begin{array}{l}\text { Sig. (2- } \\
\text { tailed) }\end{array}$} \\
\hline & & & & & Lower & Upper & & & \\
\hline $\begin{array}{l}\text { Linkage to } \\
\text { local and } \\
\text { international } \\
\text { strategic } \\
\text { patterns - } \\
\text { Trained. (Post } \\
\text { and Pre } \\
\text { Incubation) }\end{array}$ & 100 & .100 & .302 & .030 & .040 & .160 & 3.317 & 99 & .001 \\
\hline
\end{tabular}

Table 4 Paired Sample Test for Connectivity. 
In table 4, this option shows the summary data of the sample. The statistics is given by $t$. The $t$ value is 3.317 and $p=0.004$. This means that a very few probability of this output occurring by chance, under the null hypothesis of no difference. Here $p<0.05$ $(p=0.004)$, thus the null hypothesis is neglected. There is a strong evidence $(p=0.004$ and $\mathrm{t}=3.317$ ). It shows that the post incubation increases the training; it improved training on average. If other training samples was considered, mean paired difference obtained in training differ from .100. It is important to see at the $95 \%$ confidence interval $(95 \% \mathrm{Cl})$. If the experiment is repeated 100 times, 95 times the true value for the difference would lie in the $95 \%$ confidence interval. From 0.40 to .160 the $95 \% \mathrm{Cl}$ is available.

\begin{tabular}{|c|c|c|}
\hline Particulars & Pre-Incubation & Post Incubation \\
\hline \multicolumn{3}{|c|}{ Access to financing including grants, commercial loans and equity. } \\
\hline Extremely Good & 22 & 23 \\
\hline Good & 14 & 15 \\
\hline Average & 32 & 33 \\
\hline Poor & 23 & 24 \\
\hline Extremely poor & 9 & 5 \\
\hline Total & 100 & 100 \\
\hline
\end{tabular}

Table 5 Analysis of MSME for Finance in Pre-Incubation and Post-Incubation stage

Table 5 show the performance of MSME in pre and post-Incubation stage. Finance is very efficient in the post-incubation stage than the pre-incubation stage. 


\begin{tabular}{|c|c|c|c|c|c|c|c|c|c|}
\hline & \multirow[t]{2}{*}{ Observation } & \multirow[t]{2}{*}{ Mean } & \multirow{2}{*}{$\begin{array}{c}\text { Std. } \\
\text { Deviation }\end{array}$} & \multirow{2}{*}{$\begin{array}{l}\text { Std. } \\
\text { Error } \\
\text { Mean }\end{array}$} & \multicolumn{2}{|c|}{$\begin{array}{c}95 \% \text { Confidence } \\
\text { Interval of the } \\
\text { Difference }\end{array}$} & \multirow[t]{2}{*}{$\mathrm{t}$} & \multirow[t]{2}{*}{$\mathrm{df}$} & \multirow{2}{*}{$\begin{array}{l}\text { Sig. (2- } \\
\text { tailed) }\end{array}$} \\
\hline & & & & & Lower & Upper & & & \\
\hline $\begin{array}{l}\text { Access to } \\
\text { finance - } \\
\text { Trained. } \\
\text { (Post and } \\
\text { Pre } \\
\text { Incubation) }\end{array}$ & 100 & .100 & .302 & .030 & .040 & .160 & 3.317 & 99 & .001 \\
\hline
\end{tabular}

Table 6 Paired Sample Test for Finance

In table 6, this option shows the summary data of the sample. The paired t-test output is in bold. The statistics is given by $t$. The $t$ value is 3.317 and $p=0.004$. This means that a very few probability of this output occurring by chance, under the null hypothesis of no difference. Here $p<0.05(p=0.004)$, thus the null hypothesis is neglected. There is a strong evidence $(p=0.004$ and $t=3.317)$. It shows that the post incubation increases the training; it improved training on average. If other training samples was considered, mean paired difference obtained in training differ from .100. It is important to see at the $95 \%$ confidence interval $(95 \% \mathrm{Cl})$. If an experiment is repeated 100 times, 95 times the true value for the difference would lie in the 95\% confidence interval. From 0.40 to .160 the $95 \% \mathrm{Cl}$ is available.

\begin{tabular}{|l|l|l|}
\hline Particulars & Pre-Incubation & Post Incubation \\
\hline \multicolumn{2}{|l|}{ Business Development plan assistance. } & 24 \\
\hline Extremely Good & 23 & 24 \\
\hline Good & 13 & 15 \\
\hline Average & 31 & 34 \\
\hline Poor & 22 & 24 \\
\hline Extremely poor & 11 & 3 \\
\hline
\end{tabular}




\begin{tabular}{|l|l|l|}
\hline Total & 100 & 100 \\
\hline
\end{tabular}

Table 7Analysis on Pre-Incubation and Post-Incubation stage of MSME

In Business Service

Table 7 show the performance of MSME in pre and post-Incubation stage. Post incubation stage provides effective Business service than a pre-incubation stage.

\begin{tabular}{|c|c|c|c|c|c|c|c|c|c|}
\hline & \multirow[t]{2}{*}{ observations } & \multirow[t]{2}{*}{ Mean } & \multirow{2}{*}{$\begin{array}{c}\text { Std. } \\
\text { Deviation }\end{array}$} & \multirow{2}{*}{$\begin{array}{l}\text { Std. } \\
\text { Error } \\
\text { Mean }\end{array}$} & \multicolumn{2}{|c|}{$\begin{array}{c}95 \% \text { Confidence } \\
\text { Interval of the } \\
\text { Difference }\end{array}$} & \multirow[t]{2}{*}{$\mathrm{t}$} & \multirow[t]{2}{*}{$d f$} & \multirow{2}{*}{$\begin{array}{l}\text { Sig. (2- } \\
\text { tailed) }\end{array}$} \\
\hline & & & & & Lower & Upper & & & \\
\hline $\begin{array}{l}\text { Business } \\
\text { services - } \\
\text { Trained. } \\
\text { (Post and } \\
\text { Pre } \\
\text { Incubation) }\end{array}$ & 100 & .180 & .386 & .039 & .103 & .257 & 4.662 & 99 & .000 \\
\hline
\end{tabular}

Table 8 Paired Sample Test for Business Service.

In table 8, this option shows the summary data of the sample. The statistics is given by $t$. The $t$ value is 4.662 and $p=0.004$. This means that a very few probability of this output occurring by chance, under the null hypothesis of no difference. Here $p<0.05$ $(p=0.004)$, thus the null hypothesis is neglected. There is a strong evidence $(p=0.004$ and $t=4.662$ ). It shows that the post incubation increases the training; it improved training on average. If other training samples was considered, mean paired difference obtained in training differ from .100. It is important to see at the $95 \%$ confidence interval $(95 \% \mathrm{Cl})$. If the experiment is repeated 100 times, 95 times the true value for the difference would lie in the $95 \%$ confidence interval. From .103 to .257 the $95 \% \mathrm{Cl}$ is available. 


\begin{tabular}{|l|l|l|}
\hline Particulars & Pre-Incubation & Post Incubation \\
\hline \multicolumn{2}{|l|}{ Access to training, conference room, library and hot desks } \\
\hline Extremely Good & 20 & 21 \\
\hline Good & 12 & 13 \\
\hline Average & 30 & 31 \\
\hline Poor & 21 & 22 \\
\hline Extremely poor & 17 & 13 \\
\hline Total & 100 & 100 \\
\hline
\end{tabular}

Table 9: Analysis on Pre-Incubation and Post-Incubation stage of MSME for Infrastructure

Table 9 show the performance of MSME in pre and post-Incubation stage. Infrastructure is efficient in the post-incubation stage than the pre-incubation stage.

\begin{tabular}{|c|c|c|c|c|c|c|c|c|c|}
\hline & \multirow{2}{*}{ observation } & \multirow{2}{*}{ Mean } & \multirow{2}{*}{$\begin{array}{c}\text { Std. } \\
\text { Deviation }\end{array}$} & \multirow{2}{*}{$\begin{array}{l}\text { Std. } \\
\text { Error } \\
\text { Mean }\end{array}$} & \multicolumn{2}{|c|}{$\begin{array}{c}95 \% \text { Confidence } \\
\text { Interval of the } \\
\text { Difference }\end{array}$} & \multirow{2}{*}{$t$} & \multirow{2}{*}{$\mathrm{df}$} & \multirow{2}{*}{$\begin{array}{l}\text { Sig. } \\
(2- \\
\text { tailed })\end{array}$} \\
\hline & & & & & Lower & Upper & & & \\
\hline $\begin{array}{l}\text { Infrastructure } \\
\text {-Trained. } \\
\text { (Post and Pre } \\
\text { Incubation) }\end{array}$ & 100 & .100 & .302 & .030 & .040 & .160 & 3.317 & 99 & .001 \\
\hline
\end{tabular}

Table 10 Paired Sample Test for Infrastructure

In table 10 , this option shows the summary data of the sample. The statistics is given by $t$. The $t$ value is 3.317 and $p=0.004$. This means that a very few probability of this output occurring by chance, under the null hypothesis of no difference. Here $p<0.05$ $(p=0.004)$, thus the null hypothesis is neglected. There is a strong evidence $(p=0.004$ and $t=3.317$ ). It shows that the post incubation increases the training; it improved 
training on average. If other training samples was considered, mean paired difference obtained in training differ from .100. It is important to see at the $95 \%$ confidence interval $(95 \% \mathrm{Cl})$. If the experiment is repeated 100 times, 95 times the true value for the difference would lie in the $95 \%$ confidence interval. From 0.40 to .160 the $95 \% \mathrm{Cl}$ is available.

\begin{tabular}{|c|c|c|c|c|}
\hline & & $\mathrm{N}$ & Correlation & Sig. \\
\hline Pair 1 & $\begin{array}{l}\text { Business management skill - } \\
\text { Trained. (Post Incubation) \& } \\
\text { Business management skill - } \\
\text { Trained. (Pre Incubation) }\end{array}$ & 100 & .976 & .000 \\
\hline Pair 2 & $\begin{array}{l}\text { Linkage to local and } \\
\text { international strategic patterns } \\
\text {-Trained. (Post Incubation) \& } \\
\text { Linkage to local and } \\
\text { international strategic patterns } \\
\text { - Trained. ( Pre Incubation) }\end{array}$ & 100 & .973 & .000 \\
\hline Pair 3 & $\begin{array}{l}\text { Access to finance - Trained. } \\
\text { (Post Incubation) \& Access to } \\
\text { finance -Trained. ( Pre } \\
\text { Incubation) }\end{array}$ & 100 & .971 & .000 \\
\hline Pair 4 & $\begin{array}{l}\text { Infrastructure -Trained. (Post } \\
\text { Incubation) \& Infrastructure - } \\
\text { Trained. (Pre Incubation) }\end{array}$ & 100 & .975 & .000 \\
\hline Pair 5 & $\begin{array}{l}\text { Business services }- \text {-Trained. } \\
\text { (Post Incubation) \& Business } \\
\text { services -Trained. (Pre } \\
\text { Incubation) }\end{array}$ & 100 & .957 & .000 \\
\hline
\end{tabular}

\section{Table 11 Paired Sample Correlations}

Table 11 shows that the correlation for the paired samples of Business management skill, Linkage to local and international strategic patterns, Access to finance, Infrastructure and Business services in post incubation stage and pre incubation stage. The correlation of the business management skills, an infrastructure and business 
service is high compared to the finance and the linkages to local and international strategic patterns.

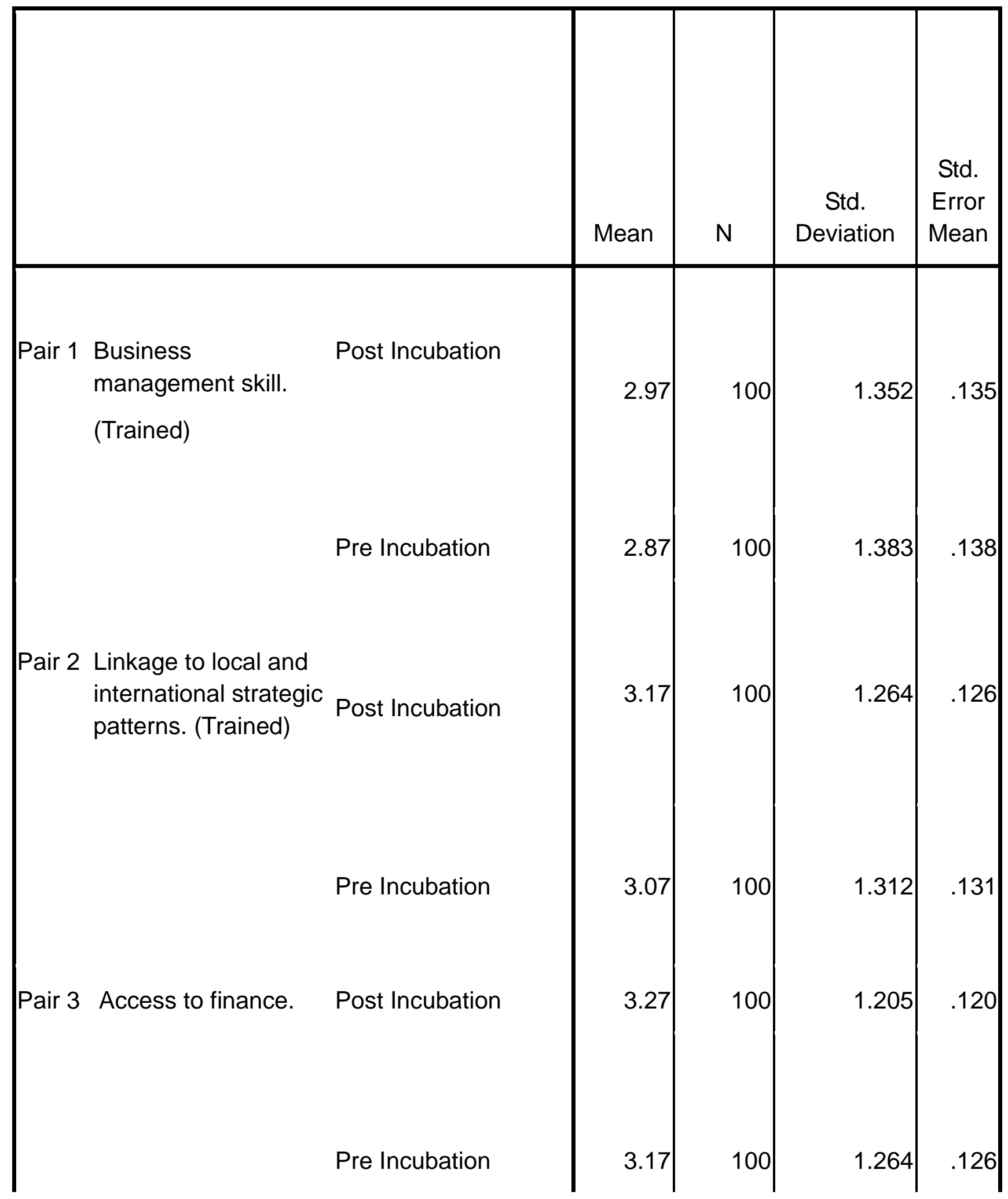




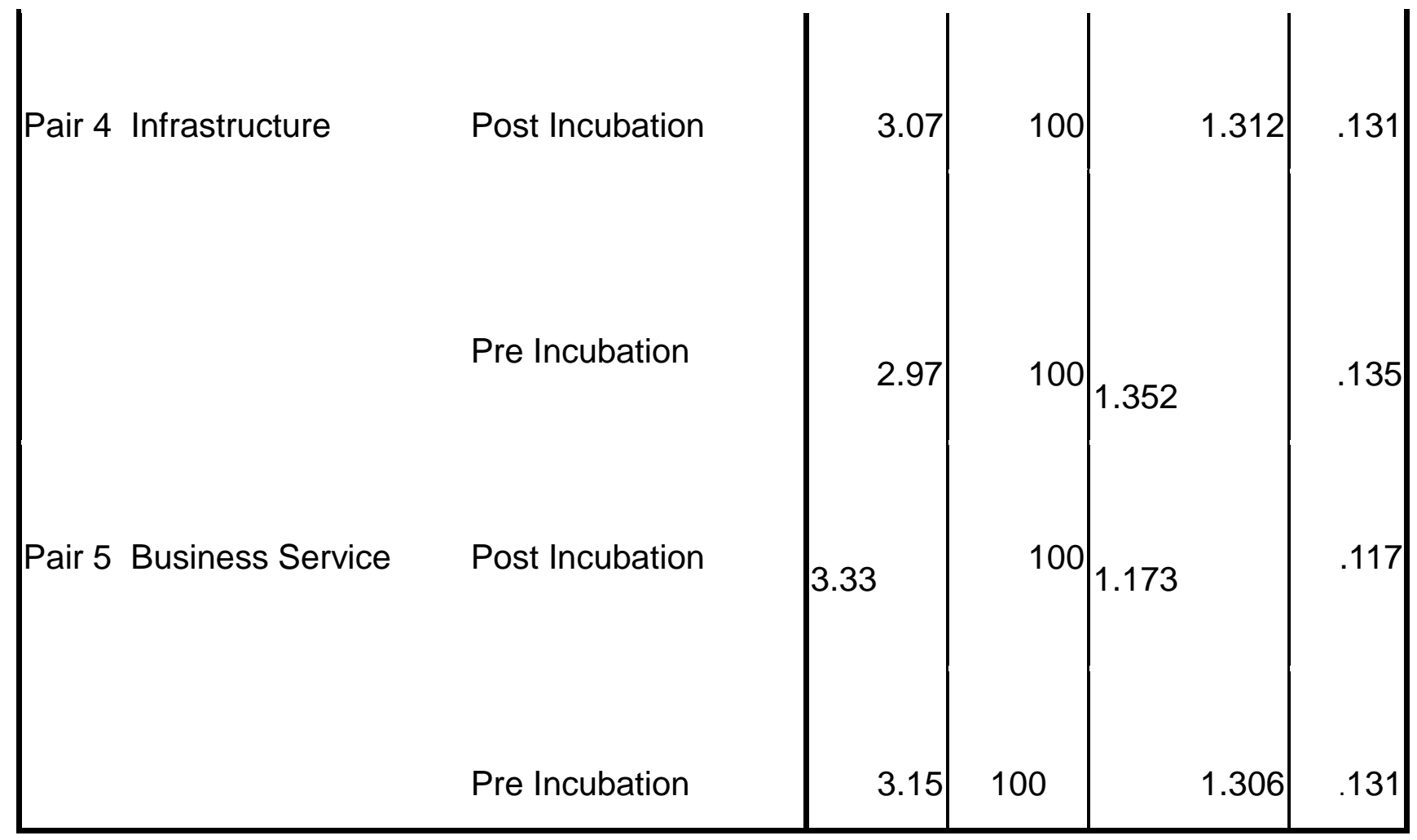

\section{Table 12 Paired Samples Statistics.}

Table 12 depicts that paired sample statistics of business management skills, linkages to local and international strategic patterns, infrastructure, business services and finance and infrastructure in both post and pre incubation stage. In post incubation stage, high Mean value, $\mathrm{N}$ value, standard deviation and standard error mean is obtained than pre incubation stage.

\section{Conclusions}

A business incubator is a company which assists new and start-up companies to grow by supplying services such as office space or management training. Business Incubator varies from technology parks and research in their commitment to start up and early stage companies. An ICT incubator provides training to the Micro Small and Medium Entrepreneurs (MSME). It includes Pre-Incubation and Post-Incubation stages. It assists MSME by providing guidance, technical assistance and consultation to entrepreneurs. The performance of 100 trained Micro Small and Medium Enterprises (MSME) in preincubation and post-incubation stage is compared. The comparison depicts that the execution of MSME in training, connectivity, finance, business service and infrastructure is effective in the post-incubation stage than the pre-incubation stage. Paired sample test for all the incubation stages in post and pre incubation period is conducted and the results show that the post incubation increases the training; it improved training on average. If other training samples was considered, mean paired difference obtained in 
training differ from .100. If the experiment is repeated 100 times, 95 times the true value for the difference would lie in the 95\% confidence interval. From 0.40 to .160 the $95 \% \mathrm{Cl}$ is available. The correlation of, an infrastructure, the business management skills and business service is high compared to the finance and the linkages to local and international strategic patterns. In the paired sample statistics, high Mean value, $\mathrm{N}$ value, standard deviation and standard error mean is acquired in post incubation stage than pre incubation stage.

\section{REFERENCES}

[1] Barrow, C. (2001). Incubator: A Realist's Guide to the World's New Business Accelerators. West Sussex, UK: John Wiley \& Sons Ltd.

[2] Rosa Grimaldi. (2005). Business incubators and new venture creation: an assessment of incubating models. Technovation. Vol.25. Issue .2. Pg. 111-121.

[3] Nicola J. Dee (2011). Incubation for Growth. Nesta.

[4] Rwanda (2012). Technology and Business Incubation a Proven model to promote technology innovation and entrepreneurship in Rwanda. International Journal of Business and Public Management. Vol.2. Pg.47-50.

[5] Abel Kinoti Meru. (2011). An Evaluation of the Entrepreneurs' perceptionof Business-Incubation Services in Kenya. International Journal of Business Administration. Vol.2. No.4.

[6] Lubica Lesakova. (2012). The Role of Business Incubators in Supporting the SME start-up. Acta Polytechnica Hungarica. Vol.9. No.3.

[7] Pralay Dey. (2012). Incubation of Micro and Small Enterprises- an approach to Local Economic Development. International Journal of Scientific and Engineering Research. Vol.3. Issue.5.

[8] Jose L. Barbero (2012). Revisiting incubation performance How incubator typology affects the results. Technological Forecasting and Social Change 79. Pg. 888-902.

[9] Nkem Okpa Obaji. (2012). Enhancing a Future version of the Nigerian SME Technology Incubation Model: Lessons for other developing countries. International Journal of Scientific and Research Publications. Vol.2. Issue 6.

[10] Simon Stephens. (2012). Measuring business incubation Outcomes: An Irish case study. Entrepreneurship and Innovation. Vol.13. No.4. Pg. 227-285.

[11] Hung Chia. (2013). Technology timing of IPOs and venture capital incubation. Journal of Corporate Finance 19. Pg.36-55.

[12] Prof M. Chandraiah. (2014). TheProspects and Problems of MSMEs Sector in India an Analytical study. International Journal of Business and Management Invention. Vol.3. Issue 8. Pg.27-40. 
[13] Wen-Hsiang Lai. Journal of BusinessResearch.Constructing business incubation service capabilities for tenants at post-entrepreneurial phase. Journal of Business Research.

[14] _Nicholas Theodorakopoulos. (2014). What matters in business incubation? A literature review and a suggestion for situated theorising. Journal of Small Business and Enterprise Development. Vol. 21. Issue: 4. pg.602 - 622 .

[15] Abetti, P.A. (2004). Government-supported incubators in the Helsinki region: infrastructure, results and best practice. Journal of Technology Transfer. Vol. 29. No. 1. Pg. 19-40.

[16] Adlesic, R.V. (2012). Social capital and business incubators performance. Economic and Business Review. Vol. 14 No. 3.Pg. 201-222.

[17] Aerts, K. (2007). Critical role and screening practices of European business incubators. Technovation. Vol. 27. No. 5, Pg. 254-267.

[18] Albert, P. (1986). Enterprise incubators - An initial diagnosis. Revue Francaise de Gestion.

[19] Allen, D. (1985). Business incubators: assessing their role in enterprise development. Economic Development Commentary. Vol. 9. No. 4. Pg. 3-8

[20] Allen, D. (1990). Value Added Contribution of Pennsylvania's Business Incubators to Tenant Firms and Local Economies. Department of Commerce. Appalachian Regional Commission and the Pennsylvania State College. Pennsylvania.

[21] Allen, D. (1986). Nurturing Advanced Technology Enterprises: Emerging Issues in State and Local Economic Development PolicY. Prager. New York. NY.

[22] Allen, D.N. (1990). Structure, policy, services, and performance in the business incubator industry. Entrepreneurship: Theory and Practice. Vol. 15. No. 2, Pg. 61-77.

[23] Allen, D.N. and Rahman, S. (1985). Small business incubators: a positive environment for entrepreneurship. Journal of Small Business Management. Vol. 23 No. 3, Pg. 12-22.

[24]AI Mubaraki, H.M. (2012). Incubating success towards Gulf cooperation council (GCC). International Journal of Innovation and Knowledge Management in Middle East and North Africa. Vol. 1 No. 1. Pg. 31-56.

[25] Al-Mubaraki, H.M. How valuable are incubators? A case illustration of their performance indicators. European, Mediterranean \& Middle Eastern Conference on Information Systems 2011 (EMCIS2011), Athens, 30-31 May, available at: www.iseing.org/emcis/EMCISWebsite/EMCIS2011\%20Proceedings/SIS2.pdf (accessed 30 March 2013).

[26] Amezcua, A.S. (2010). Performance analysis of entrepreneurship policy: which business incubators generate the highest levels of economic performance?. Frontiers of Entrepreneurship Research. Vol. 30. No. 18.Pg. 1-15. 
[27] Ascigil, S.F. (2009). Business incubators: leveraging skill utilisation through social capital", Journal of Small Business Strategy. Vol. 20 No. 1. Pg. 19-35.

[28] Autio, E. (1998). A comparative study of two European business incubators. Journal of Small Business Management. Vol. 36. No. 1. Pg. 30-43.

[29] Barbero, J.L. , Casillas, J.C. , Ramos, A. and Guitar, S. (2012), "Revisiting incubation performance: how incubator typology affects results", Technological Forecasting and Social Change, Vol. 79 No. 5, pp. 888-902.

[30] Barrow, C. (2001). Incubators: A Realist's Guide to the World's New Business Accelerators. John Wiley and Sons Ltd. Chichester.

[31] Bearse, P. (1993). The Evaluation of Business Incubation Projects: A Comprehensive Manual. The National Business Incubation Association. Athens. $\mathrm{OH}$.

[32] Bergek, A. (2008). Incubator best practice: a framework. Technovation. Vol. 28, Pg. 20-28.

[33] Birch, D.L. (1979). The Job Generation Process MIT Programme on Neighbourhood and Regional Change. MIT. Cambridge. MA.

[34] Bollingtoft, A. (2012). The bottom-up business incubator: leverage to networking and cooperation practices in a self-generated, entrepreneurial-enabled environment. Technovation. Vol. 32. No. 5. Pg. 304-315.

[35] Bollingtoft, A. (2005).The networked business incubator-leveraging entrepreneurial agency?. Journal of Business Venturing. Vol. 20 No. 2, Pg. 265-290.

[3] Brooks, O. (1986). Economic development through entrepreneurship: incubators and the incubation process. Economic Development Review. Vol. 4 No. 2. Pg. 24-29.

[37] Brown, S.J. (2004). Minding and mining the periphery. Long Range Planning, Vol. 37. No. 2, Pg. 143-151.

[38] Brown, S.J. (1998). Organizing knowledge. California Management Review. Vol. 40. No. 3. Pg. 90111.

[39] Brown, S.J. (2001). Knowledge and organisation: a social practice perspective. Organizational Science. Vol. 12. No. 2 Pg. 198-213.

[40] Bruneel, J. (2012). The evolution of business incubators: comparing demand and supply of business incubator services across different incubator generations. Technovation. Vol. 32. No. 2. Pg. 110121.

[41] Bugliarello, G. (1998). Knowledge parks and incubators. in Dorf. R.C. (Ed.). The Handbook of Technology Management. Vol. 1. Pg. 41-49. 
[42] Buys, A.J. (2007). Key success factors for business incubation in South Africa: the Godisa case study. South African Journal of Science. Vol. 103. Pg. 356-335.

[43] Cammarata, K. (2003). Self-Evaluation Workbook for Business Incubators. NBIS Publications. Athens. $\mathrm{OH}$.

[44] Campbell, C. (1989), "Change agents in the new economy business incubators and economic development”, Economic Development Review, Vol. 7 No. 2, pp. 56-59.

[45] Campbell, C. (1985). Stalking the latent entrepreneur: business incubators and economic development. Economic Development Review. Vol. 3. No. 2. Pg. 43-49.

[46] Castells, M. (1994). Technopoles of the World: The Making of the 21st Century Industrial Complexes. Routledge. London.

[47] Chan, K.F. (2005). Assessing technology incubator programs in the science park: the good, the bad and the ugly. Technovation. Vol. 25. No. 10 Pg. 1215-1228.

[48] Chen, C.J. (2009). Technology commercialization, incubator and venture capital,and new venture performance. Journal of Business Research. Vol. 62. No. 1. Pg. 93-103.

[49] Colombo, M.G. (2002). How effective are technology incubators? Evidence from Italy Research Policy. Vol. 31. No. 7. Pg. 1103-1122.

[50] Connell, D. (2010). Exploding the Myths of UK Innovation Policy: How 'Soft Companies' and R\&D Contracts for Customers Drive the Growth of the Hi-Tech Economy. Centre for Business Research. University of Cambridge. Cambridge.

[51] Contu, A. (2000), Comment on Wenger and Yanow. Knowing in practice: a 'delicate flower' in the organizational learning field. Organization. Vol. 7. No. 2. Pg. 269-276.

[52] Contu, A. (2003). Re-embedding situatedness: the importance of power relations in learning theory. Organization Science. Vol. 14. No. 3. Pg. 283-296.

[53] Danilov, V.J. (1971). The research park shake-out. Industrial Research Vol. 15. No. 5. Pg. 44-47.

[54] Dee, N.J. (2011). Incubation for Growth: A Review of the Impact of Business Incubation on New Ventures with High Growth Potential. NESTA. London. Available at: www.nesta.org.uk/library/documents/IncubationforGrowthv11.pdf

[55] Dettwiler, P. (2006). Utility of location: a comparative survey between small new technology-based firms located on and off science parks implications for facilities management. Technovation. Vol. 26. No. 4. Pg. 506-517.

[56] Ebbers, J.J. (2013). Networking behavior and contracting relationships among entrepreneurs in business incubators. Entrepreneurship Theory and Practice. Vol. 38. No. 5. Pg. 1159-1181. 
[57] Eshun, J.P. (2009). Business incubation as strategy. Business Strategy Series. Vol. 10. No. 3. Pg. 156-166.

[58] Felsenstein, D. (1994). University-related science parks: 'seedbeds' or 'enclaves' of innovation?. Technovation. Vol. 14. No. 2. Pg. 93-110.

[59] Ferguson, R. (2004). Science parks and the development of NTBFs: location, survival and growth. The Journal of Technology Transfer. Vol. 29. No. 1. Pg. 5-17.

[60] Fry, F.L. (1987). The role of incubators in small business planning. American Journal of Small Business. Vol. 12 No. 1.Pg. 51-61.

[61] Goldberg, A.I. (1996). Developing an effective technological incubator: the experience of Israel. Industry and Higher Education. Vol. 10. Pg. 371-376.

[62] Gower, S. (1996). Evaluating British science parks as property investment opportunities. Journal of Property Valuation and Investment. Vol. 14. No. 2. Pg . 24-37.

[63] Gower, S.M. (1996). Assessing the management of science parks in the UK. Property Management. Vol. 14. No. 1. Pg. 30-38.

[64] Grimaldi, R. (2005). Business incubators and new venture creation: an assessment of incubating models. Technovation.Vol. 25 No. 2. Pg. 111-121.

[65] Hackett, S.M. (2004). A systematic review of business incubation research. The Journal of Technology Transfer, Vol. 29 No. 1, pp. 55-82.

[66] Hackett, S.M. (2008). Inside the black box of business incubation: study B - scale assessment, model refinement, and incubation outcomes. The Journal of Technology Transfer. Vol. 33. No. 5. Pg. 439-471.

[67] Hamilton, E. (2011). Entrepreneurial learning in family business: a situated learning perspective. Journal of Small Business and Enterprise Development. Vol. 18 No. 1. Pg. 8-26.

[68] Hannon, P. (2005). Incubation policy and practice: building practitioner and professional capability. Journal of Small Business and Enterprise Development. Vol. 12. No. 1.Pg . 57-75.

[69] Hannon, P. (2001). UK incubators: identifying best practice.

[70] Hannon, P (2003). Are incubators good for business? Understanding incubation practice - the challenges for policy. Environment and Planning C: Government and Policy. Vol. 21. No. 6. Pg. 861-881.

[71] Hansen, M.T. (2000). Networked incubators: hothouses of the new economy. Harvard Business Review. Vol.78. No. 5. Pg. 74-84.

[72] Hansson, F. (2007). Science parks as knowledge organisations: the 'ba' in action?. European Journal of Innovation Management.Vol. 10. No. 3. Pg. 348-366. 
[73] Hisrich, R.D. (1988).The university and business incubation: technology transfer through entrepreneurial development. The Journal of Technology of Transfer. Vol. 13. No. 1. Pg. 14-19.

[74] Hoang, H. (2003). Network-based research in entrepreneurship - a critical review. Journal of Business Venturing. Vol. 18. No. 2. Pg. 165-187.

[75] Honig, B. (2007). Social capital and the modern incubator: a comparison of in-group and out-group social networks. Frontiers of Entrepreneurship Research. Vol. 27. No. 15. Pg. 1-14.

[76] Hughes, M. (2007). Stimulating dynamic value: social capital and business incubation as a pathway to competitive success. Long Range Planning. Vol. 40. No. 2. Pg. 154-177.

[77] Jack, S.L (1999). Entrepreneurship education within the enterprise culture: producing reflective practitioners. International Journal of Entrepreneurial Behaviour and Research.Vol. 5. No. 3. Pg. 110-125.

[78] Jones, O. (2010). Learning in owner-managed small firms: mediating artefacts and strategic space. Entrepreneurship and Regional Development, Vol. 22 Pg. 649-673.

[79] Kang, B.J. (2004). A study on the establishing development model for research parks. The Journal of Technology Transfer. Vol. 29. No. 2. Pg. 203-210.

[80] Karatas Ozkan, M. (2005).University incubators in the UK. International Journal of Entrepreneurship and Innovation. Vol. 6. No. 1. Pg. 401-421.

[81] Ketchen, D.J. (1993) Organizational configurations and performance: a comparison of theoretical approaches. Academy of Management Journal. Vol. 36. No. 6. Pg. 1278-1313

[82] Khalid, F.A. (2012).Third-generation business incubation practices in Malaysian ICT incubators a bridge too far. American Journal of Management.Vol. 12. Pg. 88-107.

[83] Knopp, L. (2007). The State of the Business Incubation Industry. NBIA. Athens. $\mathrm{OH}$.

[84] Kuratko, D.F (1987). Small business incubator for local economic development. Economic Development Review. Vol. 5. No. 2.pg. 49-55.

[85] Lalkaka, R. (2001). Best practice in business incubation: lessons (yet to be) learned. Belgian Presidency International Conference on Business Centres: Actors for Economic and Social Development, European Union, Brussels.

[86] Lalkaka, R. (2002). Technology business incubators to help build on innovation based economy. Journal of Change Management.Vol. 3. No. 2. pp. 167-176.

[87] Lalkaka, R. (2006). Technology business incubators: critical determinants of success. Annals of the New York Academy of Sciences. Vol. 7 .No. 8. Pg. 270-290.

[88] Lalkaka, R. (1996). Business Incubators in Economic Development: An Initial Assessment in Industrialising Countries. United Nations Development Programme. New York. NY. 
[89] Lalkaka, R. (1999). Nurturing entrepreneurs, creating enterprises and technology business incubation in Brazil. Proceedings of the International Conference on Effective Business Development Services. Rio de Janeiro.

[90] Lee, J.J. (1999). Small business incubators: a positive environment for entrepreneurship. Journal of Small Business Management. Vol. 42. No. 4. Pg. 418-426.

[91] Lee, S.S. (2004). A comparison of critical success factors for effective operations of university business incubators in the United States and Korea. Journal of Small Business Management. Vol. 42. No. 4. Pg. 418-426.

[92] Lewis, D.A. (2001) .Does Technology Incubation Work: A Critical Review of the Evidence. US Department of Commerce Economic Development Administration. Washington. DC.

[93] Lewis, D.A (2011). Incubating Success Incubation Best Practice that Lead to Successful New Ventures. Institute for Research on Labor Employment and the Economy. University of Michigan. Ann Arbor. MI.

[94] Lichtenstein, G.A. (1992). The Significance of Relationships in Entrepreneurship: A Case Study of the Ecology of Enterprise in Two Business Incubator. The National Business Incubation Association, Athens, $\mathrm{OH}$.

[95] Lofsten, H. (2002). Science parks and the growth of new technology-based firms-academic-links innovation and markets. Research Policy. Vol. 31. No. 6. Pg. 859-876.

[96] Lumpkin, J.R. (1988). Screening practices of new business incubators: the evaluation of critical success factors. American Journal of Small Business. Vol. 12. No. 4. Pg.59-81.

[97] McAdam, M. (2006). The networked incubator: the role and operation of entrepreneurial networking with the university science park incubator (USI). International Journal of Entrepreneurship and Innovation. Vol. 7. No. 2. Pg. 87-97.

[98] McAdam. (2007). Building futures or stealing secrets? Entrepreneurial cooperation and conflict within business incubators. International Small Business Journal. Vol. 25. No. 4. Pg 361-382.

[99] McAdam, M. (2008). High tech start-ups in university science park incubators: the relationship between the start-up's lifecycle progression and use of the incubator's resources. Technovation.Vol. 28 No. 5, Pg. 277-290.

[100] Markley, D.M. . (1995). Sustaining rural economic opportunity. American Journal of Agricultural Economics. Vol. 7. No. 5.Pg. 1259-1265.

[101] Marlow, S. (2012). Analyzing the influence of gender upon high technology venturing within the context of business incubation. Entrepreneurship Theory and Practice. Vol. 4. No. 36. Pg. 655-676.

[102] Merrifield, D.B. (1987). New business incubators. Journal of Business Venturing. Vol. 2. No. 4.Pg. 277-284. 
[103] Mian, S.A. (1996). Assessing value-added contributions of university technology business incubators to tenant firms. Research Policy.Vol. 25. No. 3. Pg. 325-335.

[104] Mian, S.A. (1997). Assessing and managing the university technology business incubator: an integrative framework. Journal of Business Venturing. Vol. 12 No. 4, pp. 251-285.

[105] NBIA (1996). Business Incubation Works. NBIA. University of Michigan, Ann Arbor, MI.

[106] Nowak, M.J. (2000). The virtual incubator: managing human capital in the software industry. Research Policy. Vol. 9. No. 2. Pg. 125-134.

[107] OECD (1999). Business Incubation International Case Studies. OECD Publications. Paris.

[108] Patton, D. (2009). Elements that underpin high-tech business incubation processes. The Journal of Technology Transfer. Vol. 34. No. 6. Pg. 621-636. 